\title{
Formation of human Capital in the informal and its interaction in the Congolese economy.
}

\author{
Victor Kagni \\ Master Assistant CAMES, Faculty of Economics \\ Marien Ngouabi University, Congo Brazzaville
}

\begin{abstract}
This reseach aims to highlight the formation of human capital in the informal sector as well as its collective and individual valorization in Congolese economic. The socioeconomic reproduction of formal education in the informal sector, with $70.1 \%$ of activities and $75 \%$ of jobs in the Congo, makes it possible to overcome market and state failures. The formation of human capital in informality passes through channels linked to social, physical and natural capital through inter- and extra-referential interaction, which contribute to the integration of populations, to the development of their capabilities and to the Consolidation of human capital in the determination of endogenous growth. The modeling of informal and formal interaction shows that the expected utility of the informal with an intensity of 72 seems more important than that of the formal one evaluated at 59. The two sectors are complementary and allow the populations to improve their property $B e$ in one as in the other according to the capacities of each and the economic opportunities with a view to ensuring social stability and security.
\end{abstract}

Keywords: Formation, human and social capital, informality, interaction, integration

\section{INTRODUCTION}

The basic institution of fomation would be the school, a mechanism for coordinating the supply and demand for education and the formation of human capital (Romer, 1986; Lucas, 1988), but it would not be the only one. The generalization of schooling in developing countries is not synonymous with the good quality of education and human capital in these countries.

The overcrowded classes, the lack of educational resources and corruption would have made teaching ineffective. The race for diplomas would not be synonymous with the accumulation of human capital, because the environment does not lend itself to innovation and knowledge transfer. This implies the existence of other mechanisms of coordination and integration or transmission channels (Montalieu T, 2001) such as basic education nuclear, linear, exogamique, informal, work, traditional values etc. The average gross enrolment rate in primary school in the Congo would be $110.9 \%$, the early and advanced age of some pupils in a cycle in which they were not to be explained the $10.9 \%$. At the end of primary, this net rate is estimated at $91.4 \%$ with a ratio (students/teachers) of 44.44 . In secondary school this average rate is reduced to $54.5 \%$ with a pupil/teacher ratio of 18.68 .

This improvement in ratios presages the breakdowns explaining the rates, of inactivity is estimated at $30 \%$, of activity estimated at $70 \%$, of unemployment estimated at $11.2 \%$ and of salaried activity estimated at 58.8\% (economic outlook in Africa of the OECD, table 19 and 20, 2017). $46.5 \%$ of the population in the Congo would live below the poverty line (OECD, table 14 , 2017). Populations supposed to live above the poverty line would represent $23.5 \%$ of the labour force. This implies income inequalities (Pickety, 2013, 2014) generated by human capital with a Gini index of 48.9\% in 2011, up from 2005 (47.3). The consumption share of the 
$10 \%$ poorest would be $1.6 \%$ and that of the $10 \%$ richest of $37.9 \%$ in the Congo, representing a revenue gap of 36.3 points in 2011 up from 2005 (35 points). The incomes of the richest represent 24 times those of the poorest. These poor and those of the intermediate décilles would supplement their incomes in the informal sector, a common practice among all Congolese (Kabatakaka B., 2014). These inequalities of income juxtaposed with the weakness of public education spending representing 5.53\% of GDP in 2017 (World Bank: World Perspective site) in the Congo, would explain the inequalities and school breaks, taken over by the informal (The $3 / 4$ of the activities are in the informal, according to www.portail.242.info/). It is the informal sector that trains most of the skilled workers in the Congo, who would be awarded diplomas by valuing the acquis. That is why the subject, "Formation of human capital in the informal and its interaction in the Congolese economy", is of paramount importance as these workers and activities making the daily life of all Congolese as needed.

\section{Review of literature}

\section{DISCUSSIONS}

The interaction and role of the informal sector in an economy is a peculiarity of developing economies around sectoral dualism (Lewis, 1954; Fields, 1975). The modeling of this interaction revolves around two approaches: classical and structural

The classical approach compares the informal sector to the pure and perfect competition market. State failures (Gouévitch J. P., 2002); the crises (Fontaine L. \& All., 2010) and the poor quality of the institutions, would have fostered the emergence of the informal sector and convergence towards the minimum state (F. A. Hayek, 2013; Von Meses, 2014). But the minimal protective State would have confiscated as well as rentes, private property, rationing entrepreneurship and innovation. Poorly defined property rights and market imperfections would encourage agents to prefer predation activities to productive activities (Gelb, 1988; Auty, 1990) which revolve around the financing of projects of dubious profitability, by economic operators and Governments in rentes economic. This explains the ineffectiveness of formal institutions, structural adjustments, failures of development strategies (Assidon, 2002) for sarefact basic needs (Guillaumont in Montalieu) whose education would have aroused the liberation of the education sector, with the current proliferation of private schools. But the price to pay on a cycle is dessuasif for the poor as well as private clinics.

It is in the informal sector that these poor people are trying to sarefact their basic needs. The financing of these needs goes through Tontines (Jain J., 2009), private and collective savings, contributions from the elements of the reference, the development of microfinance (Lelart M., 2000; Djadé K., 2011) and the informal exchange (Yallou S., 2012). Several activities related to the trade in details (Shaudel S. \& alls 1978), Transport (Piozin F., 1984), restoration (ElsawyEfe J., 2010; Maata B., 2012), to the circular economy (Miller F. P. \& Alls, 2010; Cissé O., 2007), to the Social and solidarity Economy (Llena C., 2012), to Industry (Bahouayila B., 2014), to agriculture around the forms of work organization and mutual assistance, to the creation of enterprises (Bernard B. \& All, 2013) developed On the margins of formal institutions to compensate for market and state failures. The activities of the informal sector concern everyone in developing countries and in Africa in particular to perfect the problems of unemployment (Maata B., 2012), monetary poverty or income supplement. According to the authors, the freedoms of action in the sector are individual and collective (www.portail.242.info/).

This informal labour force, because of the interlocking of formal and non-formal activities, of the subjugation resulting from its importance (Mozere L., 2000), of its social reproduction (Kabatakaka B., 2014), of the social lift which is down, lives Small jobs in black revolving 
around fraud, counterfeiting, piracy, bribes etc. (Gurevitch J., 2002). Informality (Mozere L., 2000) would be a solution to drive away misery (Llena C., 2012) and survive in developing countries (Bilal P., 2004) by "coping". Arbitrariness, the regulatory complication would have blackened the work for the survival of the populations (Savey A., 2015). Black Workers (Delorme G., 1992) would be in a trap of social informality as a result of recruitment through social capital. The network and the social link contribute to the integration of the excluded from the formal sector. For the classics, informality can be an alternative to the modern economy (Lévesque B. \& All, 2000), Passenger (De Herdt T. \& All, 2000) during periods of social, societal and economic transition to formal organizations related to the structuralist approach.

The structuralist approach poses the problems of morality, servitude, crimes, bankruptcy of the welfare state, tax revenues less in the financing of the economic and social, injustice and existence of inequalities (the problematics of Everything and/or nothing Paretienne, of egalitarianism Rawlsienne, of capability Amartyaienne etc. having contributed theoretically to social justice and Trickle down), illegality, poor quality of institutions etc. (Fontaine L. \& All, 2010). Informality creates under-financialisation, lack of savings, chronic under-investment, poverty etc. (Djadé K., 2011). It would maintain populations in marginality and reduce the role of the State in societies (Lauter B., 2004) because of illegal activities (Mozere L., 2000). The informal sector would not secure incomes and social workers (Lawson F. \& All, 2014). Informality poses a dilemma between the protection of children and child labour which is a reality in developing countries (Mulakirwa G., 2014). Women would be the most vulnerable entity in the labour market that is busier in the informal sector (Etoughé Efe J., 2010). But the moral and cultural brakes, and the malediction related to extraversion of developing economies in natural resource are undercutting the development of African countries and of Congo in particulary.

The two currents are unanimous on the importance of the informal sector in developing economies. It is a dynamic economy (Maldonado C. \& All, 2001; Developing world, 2014), which would weigh $80 \%$ of the GNP of some developing countries (Gourévich J., 2002).

The tontines commonly call "Likélemba" (Mayoukou C., 1994) concern all social strate to Congo and to Haiti (Jain J., 2009); The Restoration (Maléwa) Street to Gabon (Elsawy-Efe J. 2010) and to Congo, as well as divisibility concern small incomes and the poor. There are problems of public health and schooling of children and women employed in the informal circular economy in Dakar (Cissé 0., 2007), Mali, RCA...

The informal being part of the invisible, contributes by the formation of human capital (education, health, food), social (reseautage, social link), natural (societal), self-sustaining economic growth or endogenous. Well-trained human capital is suitable for negotiations and conflicts (Lipst in Badirou Daoud, Abdoulaye Dramané, 2016).

Human capital becomes a source of income inequalities (economic Alternatives, 2017, 2018), according to the theories of the signal in the labour market because the diploma makes to cultivate the delicacies of deprivations in the economy of rentes.

The degree of supervision of the labour market in Congo of 38.8 in 2016 (site perspectives monde consulted in February 2017), is a godsend for the informal sector that represents at least $70 \%$ of economic activities and at least $75 \%$ of jobs in Congo. 
The low funding of the education system or its stagnation as is the case in other countries (economic Alternatives, 2018) makes the formation of learners ineffective, determinant in primary and secondary education (Aghion and Cohen, 2004).

\section{Problematic, hypotheses and objectives}

Sectoral dualism between formal and informal (fields G., 1975) would be a characteristic of developing countries due to the failure, incompleteness and imperfection of States and markets, amplified by crises, adjustment plans, etc. Informality would be endowed with human capital (Romer P. \& All, 1986) very important and operational, hence:

The problem of knowing: how does this informal human capital form and contribute to the Congolese economy?

The existence of reseaux: family, referentials, exogamiques, solidarity, informal and formal interactional as a result of socio-economic reproduction, implies the existence of channels of coordination between school breaks, unemployed, poor, Precarious, marginal etc. of the formal sector and of the operators (workers) of the informal. Informality would be expected utility more important than formality in the Congolese economy but implies the existence of inequities and instability in a rente economy.

It was, from a modelling of the interaction between the formal and informal sector on a game structure that will be constructed, to analysis of the learning mechanisms in the informal sector and the assessment of the effects in terms of utility in The Congolese economy and welfare.

\section{METHODOLOGY \\ Interaction and informal human capital formation}

The informal is a lever for growth, consolidating global demand. Can we talk about complementarity, palliative or alternative of the informal on the formal?

To answer this question, the construction of a complete and imperfect information game seems opportune because of the simultaneous actions of the two sectors. The informal (INF) and the formel (FOR) will be players, each player will have two strategies: the activities of his sector (AS) and the formation in his sector (FS), each player has a payment function according to the statistics linked to each strategy $(\mathrm{Ti}, \mathrm{i} \in \mathrm{N})$. $\mathrm{N}$ will be players set such as $\mathrm{N}=\{\mathrm{INF}, \mathrm{FOR}\} ; \mathrm{Si}, \mathrm{i} \in \mathrm{N}$ the set of strategies such as $\mathrm{Si}=\{\mathrm{AS}, \mathrm{FS}\}$; ui(AS, FS), $\mathrm{i} \in \mathrm{Ti}$ is the payment of player $\mathrm{i}$. The perfect knowledge of the economic structure implies its reproduction by the economic agents. A representation of this game through a matrix structure summarizes the interactions through the following hypotheses:

Activities in the formal sector would represent $29.9 \%$ and those in the informal sector $70.1 \%$ (EESIC 1 and 2); The 38.4\% who would be out of school in primary education seem to be doing their formation in the informal for their socio-economic integration; At the end of the secondary level formal sector formation would represent 44\% (EESIC 1 and 2, 2011 and 2014); Formal sector activities would be reproduced at about 80-90 per cent in informal formation and the 75 per cent of informal jobs contribute to formation in this sector, and provide services that benefit all populations depending on their purchasing power. Because of the economic reproduction of the formal in the informal, the populations formed in both sectors are operational in the economy according to their needs or opportunites. The confrontation between the players FOR and INF through the AS and FS strategies generates the payments or dividends in human, social and natural capital that presiding growth in Congo, as follows: 


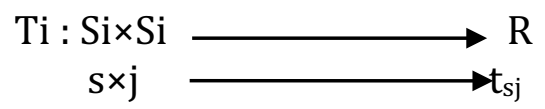

$t_{s j} \in R$ (set of real numbers) would be the payment of player $i \in N$ related to the FOR and INF strategies with $s \times j \in \mathrm{Si} \times \mathrm{Si}$. The structure of the game is such that:

Tablen $^{\circ} 1$ : game of matrix

\begin{tabular}{|c|c|c|c|}
\hline & \multicolumn{2}{|c|}{ Informal Sector (INF) } \\
\hline & & AS & FS \\
\hline \multirow[t]{2}{*}{ Formal Sector (FOR) } & AS & $(29,9 ; 70,1)$ & $(90 ; 75)$ \\
\hline & FS & $(75 ; 90)$ & $(44 ; 38,4)$ \\
\hline
\end{tabular}

Source: Personal construction from analysis data (EESIC 1 \&amp; 2, 2014)

The formal sector represents the player line and the informal, the player column. The first component of each winning couple corresponds to the payment of the player FOR and the second to the payment of the player INF. The research of equilibriums (with the conditions of existence and uniqueness) in game theory goes through several strategies whose dominance does not generate any solution; Nash's equilibrium in pure strategies generates two solutions: $(\mathrm{FS}, \mathrm{AS}) \equiv(75,90)$ and $(\mathrm{AS}, \mathrm{FS}) \equiv(90,75)$. The absence of a single solution implies the existence of non-rival and non-excluded sectors in a sort of mixed economy. One can speak of complementarity between the two sectors for the same strategy, the valorisation of capital (human, social, natural etc.) in the determination of growth. This mix for the same socioeconomic and political cohesion (uniqueness) allows us to use a mixed strategy, of probabilities to play each strategy of a player. If $\mathrm{x}$ is the probability of playing AS for the formal sector then $\mathrm{x}^{\prime}=(1-\mathrm{x})$ will be its probability of playing FS. If $\mathrm{y}$ is the probability of playing AS for the informal sector then $y^{\prime}=(1-y)$ will be its probability of playing FS. The following conditions must be respeted: $0 \leq x, y \leq 1 ; x+x^{\prime}=1 ; \quad y+y^{\prime}=1$. The expected utilities for each sector are such that:

$\mathrm{EU}(\mathrm{FOR})=29,9 \mathrm{xy}+90 \mathrm{x}(1-\mathrm{y})+75 \mathrm{y}(1-\mathrm{x})+44(1-\mathrm{x})(1-\mathrm{y})=-91,1 \mathrm{xy}+46 \mathrm{x}+31 \mathrm{y}+44$

$\mathrm{EU}(\mathrm{INF})=70,1 \mathrm{xy}+75 \mathrm{x}(1-\mathrm{y})+90 \mathrm{y}(1-\mathrm{x})+38,4(1-\mathrm{x})(1-\mathrm{y})=-56,5 \mathrm{xy}+36,4 \mathrm{x}+51,6 \mathrm{y}+$ 38,4

The derivatives and first order conditions on these utility functions give us:

$$
\left\{\begin{array} { l } 
{ - 9 1 , 1 y + 4 6 = 0 } \\
{ - 5 6 , 5 x + 5 1 , 6 = 0 }
\end{array} \Leftrightarrow \left\{\begin{array}{l}
y=46 / 91,1=0,51 \\
x=51,6 / 56,5=0,91
\end{array}\right.\right.
$$

The best expected utilities are: EU (FOR, INF) $*=(59.39 ; 71.62)$ with EU (FOR) $<$ EU (INF) Nash's equilibrium in mixed strategy will be:

$M=\left\{(x, 1-x)=(0,91 ; 0,09) ;(y, 1-y)=(0,51 ; 0,49) ; \operatorname{EU}(F O R)^{*}=59,39 ; \operatorname{EU}(I N F)^{*}=71,62\right\}$

The informal framework would distort the existence equilibrium between the two sectors, especially as the level of corruption remains high.

\section{Reactions functions of players and correlations}

The function of the best answers of the formal sector will be:

$$
f(\text { FOR })=x= \begin{cases}1 & \text { si } y>51 / 100 \\ {[0,1]} & \text { si } y=51 / 100 \\ 0 & \text { si } y<51 / 100\end{cases}
$$


The formal sector is likely to improve the living conditions of the population $(x=1)$ through the activities of the sector if, because to its failures, the informal sector contributes to a minimum of $51 \%$ by reproducing almost all the activities of the formal. It trains all citizens $(\mathrm{x}=$ 0 ) with school breaks that would be supported at $49 \%$ by the informal sector. The formal sector remains indifferent to the informal sector if activities and training are related or do not encroach on great macroeconomic equilibria. The function of better answers from the informal sector will be:

$f(I N F)=y= \begin{cases}1 & \text { si } x>91 / 100 \\ {[0,1]} & \text { si } x=91 / 100 \\ 0 & \text { si } x<91 / 100\end{cases}$

The informal reproduces almost all the activities of the formal ( $y=1$ ) Enabling the formal sector to ensure the social welfare of the population at least $91 \%$. It forms all social vulnerabilities $(y=0)$ if the formal sector can at least exploit $9 \%$ of the trained populations. It is indifferent as long as the freedom of action is not compromised.

The following correlation table may refine the existence of formal institutional failures supported by the informal, especially in the field of human capital formation.

Table $\mathbf{n}^{\circ} 2$ : Correlations between socio-economic and institutional variables from 2005 to 2016

\begin{tabular}{|l|r|r|r|r|r|r|r|l|}
\cline { 2 - 9 } \multicolumn{1}{c|}{} & MOT & DPED & GINI & CORRUP & CONSOMEN & ETUDETERT & ETUDSEC & ETUDPRIMCOM \\
\hline MOT & & & & & & & & \\
\hline DPED & 0,83 & & & & & & & \\
\hline GINI & $-0,24$ & $-0,24$ & & & & & & \\
\hline CORRUP & $-0,17$ & $-0,46$ & 0,06 & & & & & \\
\hline CONSOMEN & 0,93 & 0,75 & $-0,29$ & $-0,16$ & & & & \\
\hline ETUDETERT & 0,98 & 0,85 & $-0,15$ & $-0,26$ & 0,88 & & & \\
\hline ETUDESEC & $-0,03$ & 0,04 & $-0,06$ & $-0,49$ & $-0,19$ & 0,11 & & \\
\hline ETUDPRIMCOM & $-0,13$ & $-0,09$ & 0,71 & 0,23 & $-0,14$ & $-0,11$ & $-0,47$ & \\
\hline
\end{tabular}

Source: Author through Excel and Evews 7 based on World Bank data from the global perspective site

MOT (f1): total labour; DPED (f2): Public expenditure on education; GINI (f3): Gini indicator; CORRUP (f4): degree of corruption; CONSOMEN (f5): household consumption; ETUDETERT (f6): Enrolment rates for tertiary studies; ETUDESEC (f7): high school enrolment rate; ETUDPRIMCOM (f8): Complete primary study

In the following functional relationships, each two-sign variable to express its correlation is either strong (+) or low (-) for the first sign, positive (+) or negative (-) for the second sign, as follows:

$$
\begin{aligned}
& \text { f1 = f1 (f2++, f3--, f4--, f5++, f6++, f7--, f8--) ; f2 = f2 (f3--, f4+-, f5++, f6++, f7-+, f8--) } \\
& \text { f3 =f3 (f4-+, f5--, f6--, f7--, f8++) ; f4 = f4 (f5--, f6--, f7+-, f8-+) ; f5 = f5 (f6++, f7--, f8--) } \\
& \mathrm{f} 6=\mathrm{f} 6(\mathrm{f} 7-+, \mathrm{f} 8--) ; \mathrm{f} 7=\mathrm{f} 7(\mathrm{f} 8+-)
\end{aligned}
$$

While informality can be associated with inequalities and corruption, correlations appear to be more or less strong with primary, secondary and public education spending, foreshadowing its importance in the Congolese economy. 
The reaction functions of both formal and informal players can be represented through the following graph called the best answers curve.

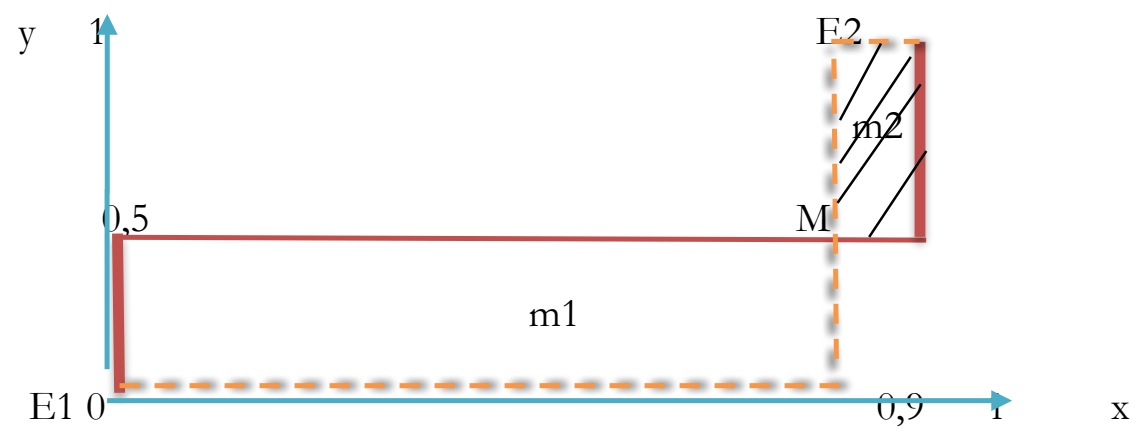

Reaction function of formal sector

Reaction function of informal sector

The Nash equilibria are obtained at the intersections of the reaction curves. Three Nash equilibria appear. M represents the best responses of the formal and informal to the welfare of the people. E1 $(0,0)$ and E2 $(1,1)$ are equilibrium in pure strategies. $\mathrm{m} 1$ and $\mathrm{m} 2$ represent convex subsets, formal sector failures supported by the informal sector in complementary to sarefact unmet needs that value their capabilities in either sector. The set of best answers can be formalized such as:

$\mathrm{M}=\left\{(0 \leq \mathrm{x}, \mathrm{y} \leq 1) / \mathrm{EU}(\mathrm{N})^{*}\right\} \Leftrightarrow \mathrm{M} 1 \leq\left\{(0 \leq \mathrm{x}, \mathrm{y} \leq 1) / \mathrm{EU}(\mathrm{N})^{*}\right\}$ et $\mathrm{M} 2 \geq\left\{(0 \leq \mathrm{x}, \mathrm{y} \leq 1) / \mathrm{EU}(\mathrm{N})^{*}\right\}$

Two spaces are defined such as:

$\mathrm{m} 1=\left\{\mathrm{M} 1 \leq(0 \leq \mathrm{x}, \mathrm{y} \leq 1) / \mathrm{EU}(\mathrm{N})^{*}\right\} ;$

$\mathrm{m} 2=\left\{\mathrm{M} 2 \geq(0 \leq \mathrm{x}, \mathrm{y} \leq 1) / \mathrm{EU}(\mathrm{N})^{*}\right\} ; \mathrm{M}=\mathrm{m} 1 \cap \mathrm{m} 2$ et $\mathrm{M} \subseteq \mathrm{m} 1$ et $\mathrm{M} \subseteq \mathrm{m} 2$.

The projection $\mathrm{M}$ on $0 \leq \mathrm{x}, \mathrm{y} \leq 1$ in the hypothesis that these sets are convex with for image $\mathrm{EU}(\mathrm{N}) *$, separates it in two under spaces $\mathrm{m} 1$ and $\mathrm{m} 2$. The equilibrium point between the two players would be in the set of $m 1$ up to the separation line with $\mathrm{m} 2$. This supposed optimal point is such that no player can change his strategies unilaterally without ensuring social and political stability. It is a simulation of Farkas ' and Minkowski's theorem (Kagni V., 1995) allowing us to define the equilibrium of Nash which is a stationary state where no player regrets his choice in determining growth.

\section{VALUATION OF INFORMAL HUMAN CAPITAL IN THE CONGOLESE ECONOMY AND INDIVIDUAL LEVEL}

\section{Valuation in the economy}

The residual variable estimated at $113.83 \%$, inversely proportional to the Congolese economic growth (Kagni V., 2012) would move the Congo away from the "technological frontier" because of the natural capital that generates rentes whose race for captures mortgage individual freedoms or their capabilities (Sen A., 2000). The negation of the residual variable implies environmental degradation due to the rentes which presiding the Congolese GDP to about $80 \%$. These degradations weaken the capital (human, social, natural) and growth (endogenous, exogenous). Schooling in primary, secondary and higher education would determine the technological frontier (Aghion P. \& All, 2004), which seems very remote for the Congo. The weakness of human capital, the degree of corruption of the Congo estimated at 23 in 2016 
(Site: World Outlook consulted in February 2017), implies a rationing of the formal productive system relayed by the dynamics of the informal sector.

From table 2 and functional relationships, it is shown that formal institutions (MOT, DPED, ETUDETERT) would be failured with for school of primary to secondary, due to low correlations, while these two cycles would determine the human capital according to Aghion.

On the other hand, the correlations are strong and positive with the studies of the Tertiary. This implies the existence of strong inequalities in primary and corruption in the secondary which favours a minority in the formations of tertiary. Vulnerabilities would be supported by the informal education sector at $49 \%$ compared to $9 \%$ by the formal sector. Informality would be complementary to the formal in the formation of Congolese manpower. Inequalities, an increasing function of primary education, imply the previously identified school breaks, supported by the informality that has a expected utility related to vulnerabilities, more important than that of the formal, i.e.:

\section{$\mathrm{EU}(\mathrm{INF})=1,21 \times \mathrm{EU}(\mathrm{FOR})$}

The informal sector would be a positive externality of reseautage and knowledge (economic Alternatives, 2017) because of the social link for integration and the valuation of human capital. Its interaction with the Congolese socio-economic environment provides a utility of about 72 in the management of vulnerabilities. According to the studies, several production units were recorded in Congo (at least 326473) between 2009 and 2012, an increase of 16.8\% (Bahouayila B., 2014). This is a result that is close to all studies that estimate the informal at 70 and $80 \%$ in underdeveloped countries. $90 \%$ of professionals would be formed each year in the informal through traditional structures ${ }^{1}$. "Methodological guides" would be set up (OIF) to promote "self-entrepreneurship" in developing countries. The degree of supervision of the Congolese market of about 39, foreshadows a release of human action to alleviate the failures of formal institutions through reseautage.

Reseau, jobs, structures, tutors etc. would constitute an informal supply of formation and learners, filiations and sets of references, an informal demand for formation. The value of a reference depends on the capabilities of the elements of the set to value their human capital. If an element of a reference set (nuclear, linear, Exogamique) has no qualification, it's all members of the reference who mobilize for it to form. The referent who takes the initiative or the one who addresses the vulnerable for a given formation, looking for a tutor and make sures guarantees the formation. The learner itself can look for a tutor related to his professional project, so a referent has to guarantee his formation. The tutor often requires financing in kind (alcohol, food, animals etc.) and in monetary equivalent. The elements of the learner's reference are mobilized to satisfact the exigency of the master of formation. That way the exigency is satisfate or an agreement on compensation is found, coordination between the master and the learner can be done for the formation.

This reseautage is a social capital determinant of the informal human capital and therefore of endogenous growth. This social link and direct or indirect interaction between members of references sets in informal formation can be interpreted as a externality of reseau (Henin P. Y. \& All, 1994). The valorisation of knowledge can be made in both sectors because of the economic reproduction of the formal activities in the informal, but the theory of the signal

${ }^{1}$ www.francophonie.org/Structuration-de-la-formation-dans.html consulté le 20/01/2018 
vulnérabilise the knowledge that is not sanctioned by the diplomas. The majority of these vulnerabilities pay in the informal to supplement the incomes if they are in the formal or to survive at $100 \%$ in case of inequalities related to the signal. Over reseau externalities, an accumulation of human capital in the form of abilities, skills and knowledge (Mankiw N. G. \& Alls, 1992) satisfies the needs of Congolese in mechanics, welding, electronics, sewing, trade, Restoration, Financing etc. The informal sector would complement the human capital rationed by formal education.

The approach by the theory of individual abilities to learn a job and to value it makes it possible to integrate as a consumer. The ability to give value to its knowledge contributes to the individual and collective welfare in an economy of rent where everyone tries to capture it in the informal, place of preference of its circulation. The degree of formal economic freedom of 42.8 in 2016 (site Perspective monde consulted in February 2017), foreshadows a very important economic freedom left to the private and informal.

\section{Implications of informal human capital on individuals}

The social and Solidarity Economy (Kagni V., 2008, 2014) contributes to the integration of marginalized peoples as citizens and actors. This integration is a positive externality for the individual who can promote his individual freedoms and satisfy his basic needs. The individual can psychologically, physiologically and materially provide a continuance of oneself. It is useful, less frustrated, free of choice and can bring added value to the national heritage. His integration makes him a citizen capable in the sense of Sen Amartya and respectable. Respect is acquired by its ability to exercise its economic, social, legal and political freedoms. His integration offers him guarantees to borrow because of the confidence that the financial institutions can give him.

The maximization of its utility would not longer depend on intra-referential transfers but on its budgetary constraint with the possibility of transferring its utility to others (these transfers under a normal law).

Individual action contributes to national wealth regardless of the formal or informal formation of human capital. It is a market-and non-market-producing factor, therefore one of the classic determinants of growth. In return for its action, its income contributes to the future consumption (savings) and presents. Future consumption can be made for precautionary, speculative or transaction needs. Its accumulation can be the subject of transformations by the financial institutions for possible investments. Current consumption contributes to the increase in production and jobs likely to reduce unemployment. We are at the heart of micro contributions to macroeconomics. Formal and informal formation contributes to the human capital that maintain growth and individual and social welfare. Rationing of education, health, food etc. can create cyclical and structural imbalances, social tensions, inequalities, environmental degradation, etc. The integration of the individual by social link, formation and activation makes him a citizen and actor capable to reproduce the species in the evolutionary sense of the term. The informal formation would give confidence to the individual for his accomplishment in interaction with his environment. Its integration is likely to lower the ecological footprint and preserve biodiversity because of the arbitrage it can make in its way of consuming in a convex set of goods. Regulating the informal implies an increase in the costs of services, which could compromise education, a guarantee of development.

\section{CONCLUSION}

The informal sector in addition to the formal sector contributes to the formation and integration of citizens and consolidates the human capital likely to sustain growth. The market 
would be flawed because social vulnerabilities are not profitable and information about the evolution of society is out of phase with public institutions. Vulnerabilities are being created that are supported by the informal sector whose socio-economic and political integrations contribute to the general policy of underdeveloped economies. This integration by formation and activity is done on the basis of a socio-economic reproduction of the formal without going against its orientations. Human capital formed, offers to people the opportunity to promote their capacities according to the opportunities of the economy. It brings to the economy the resources necessary for self-sustaining growth. The two sectors according to the abilities offered to each individual are timely to ensure their social welfare. The factors of production can be used in the formal or in the informal. They can consume in both sectors according to their purchasing power, hence the passenger side of human vulnerabilities, in an environment where the existence of a social and natural capital contributes to the determination of human capital, to the capacities individual and collective to ensure the welfare of the people.

Can the current importance of the informal sector in human capital formation be sustainable if the public institutions are moving towards structuralist theses? Would social cohesion and security not be threatened in the structuralist hypothesis? Is corruption not going to increase when it is already high in the formal sector because of the rente? The juxtaposition of the two classical and structuralist orientations makes the daily life of the Congolese in their contributions to growth and social peace. In order to reduce the importance of the informal economy, the creation of the structures of supervision and integration of the marginals is a necessary condition without which the population growth will come to butter on the rationings of the formal sector and Strengthen the informal sector, all things remaining equal elsewhere.

\section{BIBLIOGRAPHY}

Aghion P., Cohen E. (2004), Education et croissance. Conseil d'analyse économique, 143 p.

Alternatives économiques (2017), Les dossiers, Hors-série $n^{\circ} 6,98$ p.

Alternatives économiques (2018), Les chiffres, Hors-série n¹12, 98 p.

Assidon E. (2002), Les théories économiques du développement, La Découverte, 122 p.

Auty R. M. (1990). Resource-Based Industrialization: Sowing the Oil in Eight Developing Countries. Oxford England : Clarendon Press.

Badirou Daoud, Abdoulaye Dramane (2016), Démocratie et croissance économique au Bénin, Annales de l’Université Marien Ngouabi, Vol. 16, n 1-2, pp. 49-63

Bahouayila B. (2014), Etude sur la dynamique du secteur informel au Congo, INS, 11 p.

Bernard B. et Mathey S. (2013), Export facile en Afrique : 12 modèles entrepreneuriaux : L'entrepreneur exportateur non conventionnel et informel Africain : Modèle de développement et guide pratique, Bebooks, 125 p.

Bodson P. (2004), Survivre dans les pays en développement : approche du secteur informel, L'Harmattan, 302 p.

Cissé O. (2007), L’argent des déchets : l'économie informelle à Dakar, Karthala-CREPOS, 165 p.

De Herdt T., Marysse S. (2000), L'économie informelle au Zaïre : survie et pauvreté dans la période de transition, L'Harmattan, $200 \mathrm{p}$.

Delorme G. (1992), Profession : travailleur au noir, Ouest-France, 173 p.

Djadé K. (2011), L'économie informelle en Afrique subsaharienne, L'Harmattan, 250 p.

Etoughe-Efe J.-E. (2010), La restauration informelle en Afrique subsaharienne : Sociologie d'une dépendance, L'Harmattan, $171 \mathrm{p}$.

Fiels G. (1975), Rural-urban migration, urban employment and jobsearch in less developed countries, Journal of Development Economics, n², pp. 165-188.

Fontaine L. et Weber F. (2010), Les paradoxes de l'économie informelle-A qui profite les règles ? Karthala, 276 p. Friedrich August Hayek (2013a), Droit, législation et libertés, PUF, 960 P. 
Fritzner J. (2009), Les tontines haïtiennes : Historique et microéconomie des institutions financières, Editions le Manuscrit, $208 \mathrm{p}$.

Gelb, Alan and associates (1988). Oil windfalls: Blessing or curse? Oxford University Press, for the World Bank, New York. 357 p.

Gourévitch J.-P. (2002), L'économie informelle : De la faillite de l'Etat à l'explosion des trafics, Edition Le Pré aux Clercs, $346 \mathrm{p}$.

Hénin P.-Y., Ralle P. (1994), « Les nouvelles théories de la croissance : quelques apports pour la politique économique », Revue économique, Vol. 44, nº hors-série.

Kabatakaka B. (2014), Economie informelle dans les pays en développement : Reproduction chez l'élite, Edition Omniscriptum, $204 \mathrm{p}$.

Lapeyre F., Lemaitre A. (2014), Politiques publiques et pratiques de l'économie informelle en Afrique subsaharienne, Academia, $292 \mathrm{p}$.

Lautier B. (2004), L'économie informelle dans le tiers monde, La Découverte, 121 p.

Lelart M. (2000), Finance informelle et financement du développement, Edicef, 249 p.

Levesque B. (2000), L’autre économie, une économie alternative? Association d'économie politique, Presses Universitaires du Québec, 372 p.

Lewis, W. A.(1954), Economic Development with Unlimited Supplies of Labor, The Manchester School of Economic and Social Studies, pp. 139-191

LLena C. (2012), Cochabamba : quand l'informel chasse la misère, Pedalo Ivre, 200 p.

Lucas, R. (1988), « On the Mechanisms of Economic Growth », Journal of MonetaryEconomics, Vol. 22, №. 1, pp. 342.

Ludwig Von Mese (2014), abrégé de L'action humaine, traité d'économie, Les belles lettres, 218 p.

Magniez B. (2012), La place du secteur informel dans l'économie Brésilienne : pouvoirs locaux et micro-activités de rue au Brésil. Recueil d'expériences sur le commerce de rue à Joao Pessoa, Presses Académiques Francophones, $656 \mathrm{p}$.

Maldonado C., Gaufryau (2001), L'économie informelle en Afrique francophone. Structure, dynamiques et politiques. BIT, $504 \mathrm{p}$.

Mankiw N.G., Romer D. et Weil D.N. (1992), « A contribution to the empirics of economic growth, quarterly », Journal of Economics, vol.107, no2.

Mayoukou C. (1994), Le système des tontines en Afrique : Un système bancaire, le cas du Congo, L'Harmattan, 144 p.

Miller F. P., Vandome A. F., Mcbrewster (2010), Récupération informel des déchets, Alphascript Publishing, 108 p.

Monde en développement (2014), Economie Informelle dans les pays en développement : déterminants, genre et dynamiques de l'emploi, De Boeck, n¹66, 170 p.

Montalieu T. (2001), Economie du développement, Bréal, 255 p.

Mozere L. (2000), Travail au noir, informalité : Liberté ou sujétion-une lecture des travaux relatifs à l'économie, L'Harmattan, $154 \mathrm{p}$.

Mulakirwa G. (2014), L'enfant congolais : acteur dans l'économie informelle urbaine, Omniscriptum, 52 p.

Noguès H. et Dusset A. (2007), L'économie sociale entre informel et formel : Paradoxes et innovations, Presse Universitaire Rennes, 253 p.

Pickety T. (2013), le capital au XXIe siècle, Seuil, 970 p.

Pickety T. (2014), L'économie des inégalités, La découverte, 7e édition, 128 p.

Piozin F. (1984), les transports informels urbains de personnes dans les pays en voie de développement : 100 références bibliographiques (note d'information), institut de recherche des transports, $68 \mathrm{p}$.

Romer, P.M. (1986), « Increasing Returns and Long-Run Growth », Journal of Political Economy, Vol. 94, N. 5, pp. 1002-1037.

Sauvy A. (2015), Le travail noir et l'économie de demain, Calmann-Lévy, 304 p. 
Kagni, V. (2018). Formation of human Capital in the informal and its interaction in the Congolese economy. Advances in Social Sciences Research Journal, 5(3) 95-106.

Sen A. (2000), Un Nouveau Modèle économique. Développement, Justice, Liberté., Paris, Odile Jacob, 292 p.

Shaudel S., Mettelin P., Penouil M. (1978), Les activités de transition et le secteur informel à Abidjan : études de commerce de détail sur les marchés et du secteur garage, Etudes d'économie africaine.

Yallou S. (2012), Change informel et intégration de marché en Afrique : change et intégration en Afrique, Omniscriptum, $92 \mathrm{p}$. 